Article

\title{
More Than a Checklist: Meaningful Indigenous Inclusion in Higher Education
}

\author{
Michelle Pidgeon \\ Faculty of Education, Simon Fraser University, Surrey, BC V3T 0A3, Canada; E-Mail: michelle_pidgeon@sfu.ca
}

Submitted: 31 August 2015 | Accepted: 25 November 2015 | Published: 23 February 2016

\begin{abstract}
Since the 1970s there has been increased focus by institutions, government, and Indigenous nations on improving Aboriginal peoples participation and success in Canadian higher education; however disparity continues to be evident in national statistics of educational attainment, social determinants of health, and socio-economic status of Aboriginal compared to non-Aboriginal Canadians. For instance, post-secondary attainment for Aboriginal peoples is still only $8 \%$ compared to $20 \%$ of the rest of Canada (Statistics Canada, 2008, 2013). A challenge within higher education has been creating the space within predominately Euro-Western defined and ascribed structures, academic disciplines, policies, and practices to create meaningful spaces for Indigenous peoples. Indigenization is a movement centering Indigenous knowledges and ways of being within the academy, in essence transforming institutional initiatives, such as policy, curricular and co-curricular programs, and practices to support Indigenous success and empowerment. Drawing on research projects that span the last 10 years, this article celebrates the pockets of success within institutions and identifies areas of challenge to Indigenization that moves away from the tokenized checklist response, that merely tolerates Indigenous knowledge(s), to one where Indigenous knowledge(s) are embraced as part of the institutional fabric.
\end{abstract}

\section{Keywords}

Aboriginal peoples, Canada; indigenous higher education; indigenization; post-secondary education; recruitment; retention

\section{Issue}

This article is part of the issue "Social Inclusion and Indigenous Peoples", edited by Pat Dudgeon (University of Western Australia, Australia), Waikaremoana Waitoki (University of Waikato, New Zealand), Rose LeMay (Wharerātā Group, Canada) and Linda Waimarie Nikora (University of Waikato, New Zealand).

(C) 2016 by the author; licensee Cogitatio (Lisbon, Portugal). This article is licensed under a Creative Commons Attribution 4.0 International License (CC BY).

\section{Introduction}

Higher education has a responsibility to Indigenization, that is, to empower Indigenous self-determination, address decolonization, and reconcile systemic and societal inequalities between Indigenous and nonIndigenous Canadians. Since the 1970s there has been increased focus by institutions, government, and Indigenous nations on improving Aboriginal peoples participation and success in Canadian higher education. However, disparities of educational attainment continue (e.g., from the most recently available data, $8 \%$ of Aboriginal peoples have some form of a post-secondary credential compared to $20 \%$ of non-Aboriginal Canadi- ans) (Statistics Canada, 2008, 2013). This educational disparity has repercussions to the individual, their families, and communities as lower educational attainment negatively impacts one's socio-economic status, health, and overall wellbeing. In thinking of what it means to have a truly socially inclusive society within the Canadian context, systemic barriers and inequities, along with other barriers to social inclusion (e.g., discrimination, racism, etc.) need to be addressed. In this work, Aboriginal refers to the first peoples of Canada, First Nations, Métis, and Inuit; in using the term Indigenous I am connecting myself and other Aboriginal peoples of Canada to an interconnected global community of Indigenous nations. 
Indigenous higher education began in the 1960s with the establishment of Native Education and Native Studies programs in public universities (Battiste \& Barman, 1995; Brant Castellano, Davis, \& Lahache, 2000; Stonechild, 2006) and later the development of Aboriginal student support services (Pidgeon \& Hardy Cox, 2005). While this article is focusing on public nonIndigenous institutions, it is important to acknowledge the early leaders in Indigenous post-secondary institutions who were the Gabrielle Dumont Institute (est. 1980) in Saskatchewan (Dorion \& Yang, 2000) and the Nicola Valley Institute of Technology (est. 1982) in British Columbia (Billy Minnibarriet, 2012).

Indigenization as a discourse through academic writing and research emerged the early 2000s (Mihesuah \& Wilson, 2004) and has increased in scope and depth to become a transformative movement globally. The long-term impact of this movement continues to take shape; it is hoped that future generations of Indigenous communities have different stories to tell-stories of equity, empowerment, and selfdetermination.

The purpose of this article explores what Indigenization means through institutional initiatives (e.g., policy, programs, and practices) that are aimed to support Indigenous success. To begin, the article provides a brief overview of the history of Aboriginal engagement with public post-secondary education and then transitions into exploring how the Indigenization movement has been articulated and critiqued from within and outside the academy. In understanding the landscape of Indigenization, I situate the work that I have witnessed over 10 years of research and practice in British Columbia, Canada through an Indigenous Wholistic Framework (Pidgeon, 2008a, 2014). It is used to understand how institutions have (or have not) been responding to Indigenization from Indigenous perspectives. The Framework includes the work of Kirkness and Barnhardt (1991) on the 4Rs of respect, relevance, reciprocal relationships, and responsibility; the $4 \mathrm{Rs}$ become the guiding structure for discussing the tensions within the Indigenization movement to move institutional approaches away from the tokenized checklist response that merely tolerates Indigenous knowledge(s) to one where Indigenous knowledge(s) are embraced as part of the institutional fabric. The article concludes with questioning and providing a response to: What does an Indigenized institution look like? The conclusions provide visioning of the next steps to collectively move towards becoming a socially inclusive society.

\section{An Overview of the Relationship between First Nations, Métis, and Inuit and Post-Secondary Education}

First Nations and Inuit kindergarten to grade 12 (or equivalent) is a federal responsibility as dictated through the Indian Act 1876 (and amendments) and while initially concerned with on-reserve schools now includes transfer payments to the provincial public system for Aboriginal students who attend off-reserve public schools. Métis peoples have a different historical relationship with the federal government in terms of education provision (Dorion \& Yang, 2000). This relationship changed once legal changes to $\mathrm{s.35}$ of the $\mathrm{Ca}$ nadian Constitution 1982 recognized the unique culture and rights of Métis peoples. Gabriel Dumont Institute, established in 1980, was Canada's first Métis post-secondary institution that "focused on the education through cultural research as a way of renewing and strengthening the heritage and achievement of Métis and non-status Indian peoples in Saskatchewan" (Dorion \& Yang, 2000, p. 180).

For the rest of Canada, kindergarten to postsecondary education is a provincial jurisdiction with financial transfer payments from the federal government. This unique relationship has created a dual system in that the federal government does not see itself legally responsible for the post-secondary education of Indigenous peoples (Battiste \& Barman, 1995; Paquette \& Fallon, 2014; Royal Commission on Aboriginal Peoples, 1996). Under the guise of social responsibility (rather than legal), the federal government began providing more support programs through federal funding for access programs, some academic initiatives, and financial support programs for First Nations learners, who were under the jurisdiction of the Indian Act, starting in 1970s to 1990s (Human Capital Strategies, 2005; Malatest \& Associates Ltd., 2004; Stonechild, 2006; Usher, 2009; White, Maxim, \& Spence, 2004).

Indian Control over Indian Education, a foundational Indigenous position paper written by the National Indian Brotherhood (now known as the Assembly of First Nations) in 1972, remains a corner stone in the articulation of First Nations visions for education. This document was an Indigenous response to the federal governments' White Paper, a proposed policy that aimed to change the nature of the relationship and responsibilities of the federal government to First Nations peoples. Indian Control over Indian Education clearly positioned the role of education across the lifespan (e.g., from early childhood to post-graduate education) for First Nations peoples in Canada (National Indian Brotherhood, 1972). Forty years later, the aims articulated in 1972 are even more relevant and pertinent to the conversation of what it means to meaningfully engage with Indigenization of higher education (Pidgeon, Muñoz, Kirkness, \& Archibald, 2013). Building on this history, we have seen the emergence and recent resurgence in Indigenized-programs and services and Indigenous-specific post-secondary institutions across the country (Association of Universities and Colleges of 
Canada (AUCC), 2010; Human Capital Strategies, 2005; Pidgeon, 2005, 2014; The Aboriginal Institutes' Consortium, 2005; Usher, 2009).

In many ways, Canada is in a unique moment in history as the national gaze has focused on the complexity of issues facing Indigenous communities. This national attention is influenced by the grassroots and community based advocacy such as the Idle No More Movement (e.g., http://www.idlenomore.ca) and the calls for a national inquiry for the missing and murdered Aboriginal women (e.g., http://canadians.org/sites/default/files/ publications/missing-women-factsheet.pdf). Further to this, the Truth and Reconciliation Commission (TRC) of Canada bought the nation together to witness, reflect, and react to the cultural genocide experienced by Aboriginal peoples and the ongoing intergenerational legacy of the residential school era (1831-1996). In the TRC final report and Calls to Action, there was a call for the Canadian educational system to change "in order to redress the legacy of residential schools and advance the process of Canadian reconciliation" (Truth and Reconciliation Commission of Canada (TRC), 2015b, p. 1).

Indigenization of higher education is part of this reconciliation and to move forward, all involved- Aboriginal and non-Aboriginal need to consider what Indigenization means. For example, as Indigenous researchers, faculty members, students, Elders, and staff bringing our knowledges, practices, and ways of being into this colonial space must honors and respects who we are as Indigenous peoples. Non-Aboriginals seeking this "Indigenization" of their institutions must understand what Indigenization really means, and that Indigenization can not be defined or bounded by their expectations of what it should mean. Indigenization provides insight into Indigenous envisioning for the educational experiences for the next seven generations.

\section{Indigenization: What Does It Really Mean?}

From Indigenous perspectives, Indigenization of the academy refers to the meaningful inclusion of Indigenous knowledge(s), in the every day fabric of the institution from policies to practices across all levels, not just in curriculum. Marlene Brant Castellano (2014) envisions Indigenized education to mean "that every subject at every level is examined to consider how and to what extent current content and pedagogy reflect the presence of Indigenous/Aboriginal peoples and the valid contribution of Indigenous knowledge" (para. 1). Mihesuah and Wilson's (2004) Indigenizing the Academy: Transforming scholarship and empowering communities is one of the first texts put forward by Indigenous scholars who reflect on what it meant to Indigenize the academy. It clearly laid out the challenges of this process not only ideologically but also practically from a variety of Indigenous scholars from Canada and the United States. For example, in his chapter of the same text, Taiaiake Alfred (2004) reflects on Indigenizing the academy as a process where "we are working to change universities so that they become places where the values, principles, and modes of organization and behavior of our people are respected in, and hopefully even integrated into, the larger system of structures and processes that make up the university itself" (p. 88). Cupples and Glynn (2014) explored what it meant for a group within Nicaragua's coast to form their own decolonized and intercultural university with the "aim to support political and social struggles with culturally and epistemologically appropriate modes of teaching, learning, and research" (Mato, 2011 cited by Cupples \& Glynn, 2014, pp. 56-57). Cupples and Glynn (2014) explained how the university provide access to individual students "but without losing sight of education as a collective good" (p. 57) based on principles of interculturality.

Daniel Heath Justice (2004) writing to the field of Indigenous literary studies shares lessons that are useful for other Indigenous academics, who are invested in the Indigenization of the academy. He reminds Indigenous peoples that the academy is just as much our inheritance as being part of the land and we have a right and entitlement to be part of the meaning making of this world and while we are in these spaces, "we must not forget to be both responsible and humble" (p. 101) and to "be generous of spirit, in war as well as in peace" (p. 103). These recommendations support the decolonizing work of Marie Battiste (Battiste, 1998; Battiste, Bell, \& Findlay, 2002), who views education as a tool of decolonization where Indigenous people are empowered in who they are. Other Indigenous scholars (such as Kuokkanen, 2007; Smith, 2012) argue that higher education through Indigenization is becoming decolonized and perhaps more importantly, an active resistor to the ongoing colonization of Indigenous peoples. Kuokkanen's (2007) logic of the gift refers to meaningful inclusion of Indigenous knowledge(s) within the academy. Battiste (2013) in calling on educators to decolonize their pedagogy and practices, provides a way for us to address cultural misappropriation in our institutions. This call applies to all involved in higher education, whether a government bureaucrat, policy analyst, administrator, faculty, staff, or student, Aboriginal or non-Aboriginal. She states:

"educators must reject colonial curricula that offer students a fragmented and distorted picture of Indigenous peoples, and offer students a critical perspective of the historical context that created that fragmentation. In order to effect change, educators must help students understand the Eurocentric assumptions of superiority within the context of history and to recognize the continued dominance of these assumptions in all forms of contemporary knowledge". (Battiste, 2013, p. 186) 
There are criticisms of this movement from nonIndigenous and Indigenous communities, albeit their arguments come from difference places. The critiques who are non-indigenous peoples tend to position their arguments (or questions about or resistance too) Indigenization by stating that the academy already has a cannon of knowledge in which Aboriginal knowledges are part of- so why does the academy need to Indigenize? This resistance is particularly strong in academic disciplines with long colonial legacies and an unwillingness to alter their thinking. Another group adopts a multiculturalism stance, where they argue the inclusion of Indigenous knowledges and practices means that the academy will have to include all other groups in society (e.g., race, class, gender). They push back arguing the work of Indigenizing the academy is too difficult or complex. There are yet others who put forward a fiscal argument that given the current economic cutbacks and declining enrollment, providing such institutional commitment to a relatively small percentage of the university or college community is fiscally irresponsible. While many will state, of course if they could make their institutions better for Aboriginal students they would, but to undertake that task means that they will have to devolve their power, position, and prestige to create space for other ways of knowing and being (Pidgeon, 2008a, 2014).

While criticisms, or cautions, from Indigenous scholars regarding Indigenization are framed with an awareness that this movement is occurring within a deeply seated colonial structure with long histories in the colonization of Aboriginal peoples and still influencing the ongoing colonial project (e.g., Alfred, 2004; Mihesuah \& Wilson, 2004; Paquette \& Fallon, 2014). For Indigenization to occur, Indigenous scholars argue it must also be a decolonizing process; Indigenity has to go beyond what "others" are comfortable with, beyond the tokenistic representations of culture, or one-off events, programs, and services and misrepresentations of Indigenous peoples and their cultures (Arndt, 2013; Jacobs, 2014; King \& Springwood, 2001; Lee \& Castagno, 2007; Paquette \& Fallon, 2014). These Indigenous scholars also inherently recognize these misrepresentations and forms of resistance perpetuate the colonial project of "othering" and sustain the inherent systemic racism, both overt and covert, that result in inappropriate uses of Indigenous culture and images within society.

Daniel Heath Justice (2004) aptly describes the tensions, in that if Indigenous scholars see the higher education institutions as:

"enforce[ing] an understanding of 'knowledge' as that body of mores that have emerged more from a clash of ideas than a thoughtful consideration of them....Such a goal turns our attention away from lands and cultural traditions and into inequitable power dynamics of an increasingly corporatized ac- ademic world. Such an academy may well be beyond redemption." (p. 101)

However, if the view of the academy is one of "a place of intellectual engagement, where the world of ideas can meet action and become lived reality....[It] can also be a site of significant cultural recovery work, a place where all people who are disconnected from their histories can begin their journeys homeward" (p. 102). It is this later view, where Indigenization of the academy is embodied in the work of Indigenous peoples engaging as active participants in society and higher education to the broader goals of decolonization and empowerment. The questions that remain within this movement, is what is the process of indigenization and what does a successful Indigenized institution look like? To better understand this movement, and to provide a framing of the discussion through an Indigenous lens, the next section provides an overview of the Indigenous Wholistic Framework.

\section{Indigenous Wholistic Framework: Theory and Process}

An Indigenous Wholistic ${ }^{1}$ Framework (see Figure 1) is just one way to represent Indigenous ways of knowing and being; it represents for me, as a person of Mi'kmaq ancestry a way of centering who I am as a scholar (Pidgeon, 2008a, 2014). This Framework connects not only the philosophical underpinnings of Indigenous knowledges but attempts pictorially to represent the complexity of wholistic interconnections that we have as individuals, to our communities, nations, and global communities. It recognizes that one's physical needs are linked to the spiritual, intellectual, and emotional and that living a balanced life is about meeting each of these needs sustained by one's inter-relationships. The Indigenous Wholistic Framework provides an anchor to move forward a discussion of Indigenizing the academy, in that we can locate it in place (geographically, institutionally, etc.) and see the interconnections of a broader educational system (e.g., country, province, territory) to the individual student, administrator, faculty, staff, Elder, and others in the institution and surrounding communities (Pidgeon, 2008a, 2014). This framework allows us to locate in place the Indigenous territories and lands, whether unceded or ceded through treaty, upon which post-secondary institutions were built. Acknowledging territory is increasing as an institutional practice in Canada; it acknowledges the Indigenous peoples of the area and, in a symbolic way, recognizes the colonial legacy of the institution in place and time.

As Figure 1 demonstrates the interconnections of indi-

\footnotetext{
1 Wholistic is intentionally spelled with a $\mathrm{W}$ to be mindful of the whole being; it honors the practice begun by Archibald et al. (1995).
} 
vidual to family to community (local, provincial/territorial, national, global) illustrates how an Indigenous student's educational journey or Aboriginal community engagement in research or academic programming is connected to a broader success and empowerment of Indigenous peoples. Within a postsecondary setting, for one to solely think of education as an intellectual exercise ignores keys components of the learning journey that fosters Indigenous understandings of success and well being (Pidgeon, 2008b). The 4Rs, first proposed by Kirkness and Barnhardt (1991), and later revisited by Marker (2004), are the cornerstone of my own work (e.g. Pidgeon, 2014). Other Native American scholars have also been taken up the 4Rs in their work in the US higher education system (e.g., Shotton, Lowe, \& Waterman, 2013). The 4Rs represent Indigenous perspectives on how Respect for Indigenous knowledges, Responsible relationships, Reciprocity, and Relevant programs and services can transform institutional cultures and practices for Indigenous peoples. The 4 Rs were offered by Kirkness and Barnhardt (1991) to help build understanding between Indigenous and non-Indigenous ways of thinking of supporting Aboriginal student success, in this article the 4Rs are extended to help bridge understanding of Indigenization where the Wholistic Framework centers the work from the Indigenous perspective.

Building on Figure 1, Figure 2 provides a visual representation of the interconnections in an institution between senior administration, faculty/departments, and faculty/staff/student with policies, programs, and practices. It shows the inter-relationships of the globalnational-local to higher education, particularly evident in Canada's structure of provincial jurisdiction of education but federal responsibility of First Nations, Métis, and Inuit education. Indigenization as a form of social inclusion requires recognizing the work and dedication that has happened from the grass roots of an institution to the senior executive leadership to create systemic and broader societal change.

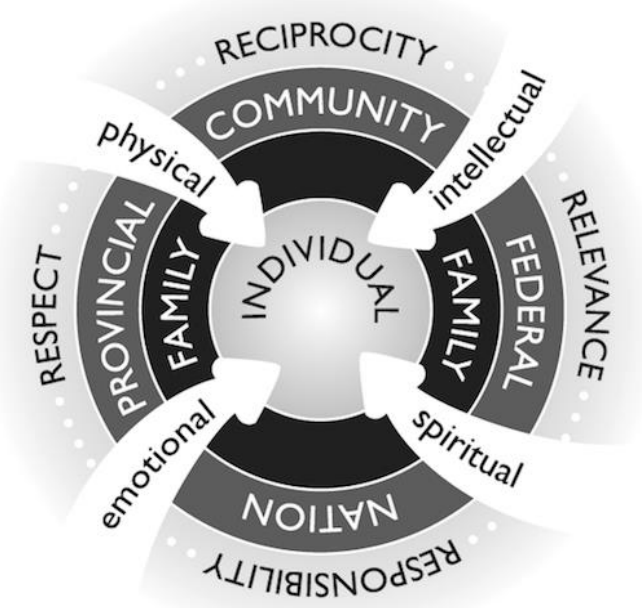

Figure 1. Indigenous Wholistic Framework.

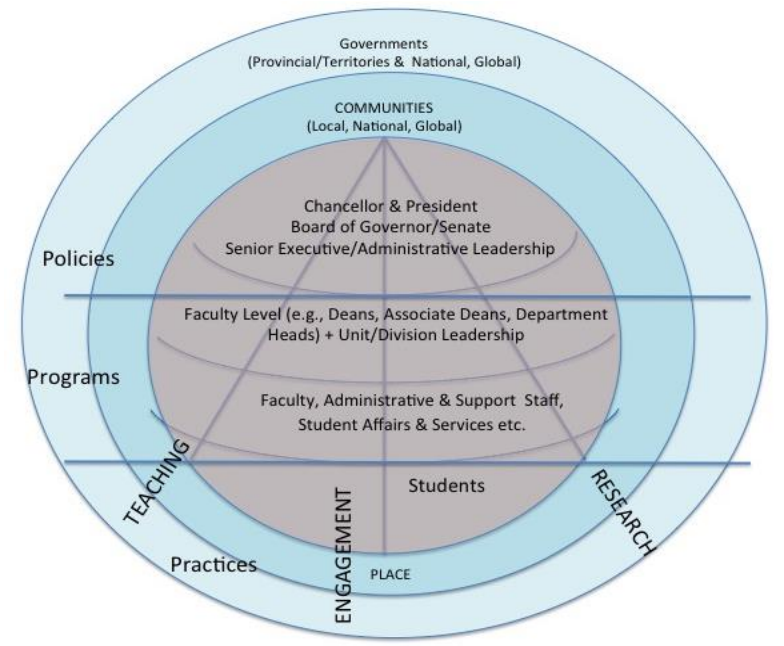

Figure 2. Visual representation of inter-connections of higher education.

\section{Lessons Learned: Indigenizing the Academy through the 4 Rs}

Indigenizing the academy is not one strategy, or one policy change-it is a culminating and complex living movement that aims to see post-secondary institutions empowering Aboriginal peoples' cultural integrity through respectful relationships through relevant policies, programs, and services. This transformation will take time and it is time. It is important to remember that post-secondary institutions are not some abstract ideal or philosophy, nor are they unknown entities; institutional structures, values, and cultures are complex and the people who reside, engage, and interact (internally or externally) with these institutional communities all shape and influence the institution. Therefore, Indigenous and non-Indigenous peoples all have a responsibility to act to transform post-secondary education to benefit all, as illustrated within the Indigenous Wholistic Framework through Responsible Relationships \& Governance; Relevance to Curriculum and CoCurricular; and Respect in Practice.

\subsection{Responsible Relationships \& Governance}

Canadian universities and colleges primarily operate on a bi-cameral governance model (e.g., senate and board of governors for universities or governance boards and education council for colleges) (Jones, 2014). The roles and responsibilities of these governing bodies are outlined in the College and Institutes Act or University Act (or comparable policy) in each province and territory. As Figure 2 illustrates, governance also encompasses the senior leadership of the President, Vice-Presidents, Deans, and Associate Deans, department heads and directors in addition to staff, faculty, and student unions and student leadership across the various areas of our campuses. 
It is important to acknowledge the Indigenous institutes, such as Nicola Valley Institute of Technology (NVIT), the En'owkin Centre, Gabriel Dumont Institute, and other Indigenous institutions operate under an Indigenous governance framework, with Elders and Aboriginal senior leadership. Their entire institution from policy to program development and pedagogical practice imbeds and honours Indigenity. However, the focus of this article is on non-Indigenous public postsecondary institutions, for this is where the meaningful inclusion of Indigenity is a challenge.

Leadership in the Indigenization movement comes from a variety of individuals and groups within and outside the institution. It is the student affairs staff working to recruit and retain Indigenous students alongside Aboriginal student services, Aboriginal academic transition programs, and other culturally relevant supports. It occurs when faculty members begin to dialogue and enact changes in their programs, curriculum, and pedagogical practices that are more inclusive, respectful, and responsible of Indigenous knowledge(s) and of the Indigenous learners in the classroom. It also is exemplified at the most senior level- the president. For example, during the period of the TRC, the University of Manitoba publically apologized for its role in the training of teachers who worked in residential schools and its overall role in the colonial project against Indigenous peoples. In July 2015, the incoming president of the University of Saskatchewan, Peter Stoicheff, publically announced that he is making Indigenization his top priority. He explained that "the university must be a leader in closing the gaps between Aboriginal and non-Aboriginal people, he continued, calling this a 'moral imperative'”(Academia Group, 2015 para. 1).

Indigenization of the academy occurs when Indigenous community members, Elders, aunties, uncles, and other family members come to the institution to support their learners and/or become involved in the governance of the institution (e.g., members on Advisory council). Community involvement (or lack of it) also highlights a tension in Indigenizing the academyCanadian higher education is primarily based on the bicameral system and in many ways operates with values and practices that are contrary to Indigenous governance models and cultural protocols. While more institutions are honouring of territory at formal and public institutional events, they can do more to ensure that the day-to-day operations of an institution, particularly related to Indigenous matters, honour and follow Indigenous models of governance (e.g., Aboriginal advisory committee; Indigenous leadership positions) and policies (e.g., Aboriginal strategic plans or specific policies).

\subsubsection{Aboriginal Advisory Committee}

Within British Columbia, there are 26 universities, colleges, and institutes, of whom 17 (65\%) have institu- tional level Aboriginal strategic plans. However, only $8 / 17$ have some form of an Aboriginal Advisory Committee, whose representatives include Elders, Aboriginal community leaders, and others who have an interest in Aboriginal higher education from within the institution. These positions are typically voluntary members from the community and staff from the institution. These advisory committees can be simply "window dressing," with limited power to make changes and simply provide the institution with a check mark of "have-it" but without influence or change on the institution itself. However, in most cases, these committees do bring together leaders from within and outside the institution and have terms of reference that forge powerful relationships and leadership within the university for Indigenous initiatives between the communities and the institution.

\subsubsection{Indigenous Leadership Positions}

Within BC's public post-secondary system, many institutions have created formal leadership positions such as Special Advisor to President (e.g., University of Victoria, Thompson Rivers University, University of British Columbia, Vancouver Community College) at the senior executive level. While some faculties have created leadership positions at the Associate Dean level for Indigenous initiatives (e.g., University of British Columbia). These positions are typically held by tenure-track professors, usually at the rank of associate or full, this academic credibility has been seen as an important "power" relationship in negotiating in the academy. At the senior administration level, these positions tend to have administrative staff of one to two people, have an operating budget for program planning and initiatives, and articulated terms of reference and goals. There are also leadership roles created under the responsibilities of a Vice President (e.g., VP Academic) or Associate Dean (e.g., Associate Dean, Academic) at the faculty level, such as a Director, who may or may not have an academic position within the institution, typically they are hired under an administrative position, and their mandate is related to implementing the institutions' $A b$ original strategic plan or implement a faculty-level plan (e.g., University of Victoria, Simon Fraser University).

The power of this senior leadership, whether from the senior executive to a faculty position, is largely dependent on how the position was negotiated within the institution, the reporting structure, budget attached to the position (e.g., financial and human resources), and most importantly, the mandate and goals of the position and the authority to enact change (e.g., scope, role, authority- symbolic or otherwise) (Pidgeon, 2014). Such positions create a unique opportunity to make systemic change through role-modeling and mentoring other in living Indigenous values and principles of governance in practice (Alfred, 2004; 
Pewewardy, 2013). Such positions have also been created in the United States, as Francis-Begay (2013) described the establishment of special advisor to the president at the University of Arizona in 1999, and noted other institutions who have also created that liaison position between the institution and tribal nations (e.g., Montana State University, University of Idaho, University of New Mexico, Washington State University, University of Oregon, Northern Arizona University, and Arizona State University) (p. 82).

First Nations Student Associations (FNSA) are also a growing component of student leadership and governance on campus. As part of the undergraduate student union for the institutions, some FNSAs have negotiated funding allocation for Indigenous-student initiatives and programming on campus that benefits Indigenous and non-Indigenous students. FNSAs and studentrepresentative positions within Senate, departments, and faculties are other opportunities for Indigenous students to have an active voice within their institutions (Pidgeon, 2008a; Pidgeon, 2014).

\subsection{Institutional Policy}

\subsubsection{Aboriginal Strategic Plans}

Institutional level policy relates to the work of the governance bodies (e.g., Senate) and the day-to-day operations of an institution and institutional-wide strategic initiatives. The majority of the 124 public universities, colleges, or institutes across Canada had some form of institutional plan which outlines the institutional mission and purpose within a three to five year cycle; these strategic reports are also accountability frameworks and reporting mechanism to the provincial ministry. For the purposes of this paper, I conducted an environmental scan of publically available strategic plans at 124 public colleges and universities in Canada, only $35 \%$ of these institutions had a specific institutionwide Aboriginal strategic plan, which was also referred to as Aboriginal Student Success Strategy or Indigenous Initiatives. Indigenous strategic plans tend to cover policy, programs, and broader institutional goals around Aboriginal student success rates.

Other policies that are important to note, are those that intentionally focus on Indigenous education, normally focusing on support Aboriginal student success. For example, the Indigenous Education Accord (Association of Canadian Deans of Education (ACDE), 2009) and the Indigenous Education Protocol for Colleges and Institutes (College and Institutes Canada, 2014b).

The ACDE (2009), with the leadership Jo-ann Archibald, John Lundy, Cecilia Reynolds, and Lorna Williams, developed the accord to enhance teacher education preparation for working with Indigenous learners and their communities. It states "recognizing the need for transformative educational change and acknowledging the unique leadership responsibilities of deans, directors, and chairs of education within Canadian university context, the ACDE supports and encourages the following goals" (p. 5): respectful and welcoming learning environments; respectful and inclusive curricula; culturally responsive pedagogies; mechanisms for valuing and promoting Indigenity in education; culturally responsive assessment; affirming and revitalizing Aboriginal languages; Indigenous education leadership; nonIndigenous learners and Indigenity; and culturallyrespectful Indigenous research (pp. 5-8).

Colleges and institutes are key providers to postsecondary education to Indigenous peoples, who represent diverse cultures, languages, histories, and contemporary perspectives (College and Institutes Canada, 2014b). The College and Institutes Canada, representing 135 public and private colleges and institutes, developed an Indigenous Education Protocol for Colleges and Institutes. This document was launched on December 31, 2014 and "underscores the importance of structures and approaches required to address Indigenous peoples' learning needs and support selfdetermination and socio-economic development of Indigenous communities" (para. 4). As of June 8, 2015, 34 colleges and institutes from Alberta, British Columbia, Manitoba, Saskatchewan, Quebec, Ontario, New Brunswick, North West Territories, and Yukon (College and Institutes Canada, 2014a) had signed this document with the commitment to the following seven principles: 1) Commitment to make Indigenous education a priority; 2) Ensure governance structures recognize and respect Indigenous peoples; 3) Implement intellectual and cultural traditions of Indigenous peoples through curriculum and learning approaches relevant to learners and communities; 4) Support students and employees to increase understanding and reciprocity among Indigenous and non-Indigenous peoples; 5) Commit to increasing the number of Indigenous employees with ongoing appointments throughout the institution, including Indigenous senior administrators; 6) Establish Indigenouscentred holistic services and learning environments for learner success; and 7) Build relationships and be accountable to Indigenous communities in support of selfdetermination through education, training, and applied research (College and Institutes Canada, 2014a).

The principles that are common to these two policies are also evident in university Aboriginal strategic plans, with the addition of the area of research (e.g., Indigenous research strategies, methodologies, and relevant research to Indigenous communities). These strategic plans often influence specific policies to be implemented regarding Indigenous students as the next section outlines.

\subsubsection{Aboriginal Specific Policies.}

In researching student experiences of university and 
college, there were notable places in institutional policy that were pertinent to the Indigenous student experience and Indigenization. The first would be around admissions, considering prior-knowledge and ensuring culturally relevant admissions processes for students. Two areas of tension around admissions are: 1) selfidentification of whether or not they are Aboriginal and 2) financial barriers. To support Aboriginal access, some institutions have developed third-party billing policy. Third party billing allows for the institution and provider of funding to directly work together and allows an Aboriginal student (or any student who is receiving funding from an outside source (e.g., not student loans, personal bank loans, or scholarships/ grants)) to not have to negotiate receipt of funding. Examples of this funding policy are on the websites of Dalhousie University, University of Victoria, and University of Manitoba. This policy creates a direct relationship between the institution and the funder and in this agreement, some institutions will "cover" fees for the student (from application, tuition, and books) and work with the Band (or other funding organization) to receive the funds.

In terms of self-identification, in an educational system where being "labelled" Aboriginal has had negative consequences for many (e.g., special education or non-academic streaming), Aboriginal students are leery of institutional requests for self-identification (Hare \& Pidgeon, 2011; Royal Commission on Aboriginal Peoples, 1996; Wotherspoon \& Schissel, 1998). While institutions may be simply asking for this information for 1) enrolment numbers and/or 2) referrals to Aboriginal student services; many students are sceptical on how that information is actually used and do not want to be labelled in any way (Pidgeon, 2008a, 2008b). As a researcher and teacher, I have observed many Aboriginal students choose not self-identify at admissions but will later in their educational journey whether it was during a visit to the Aboriginal student services centre, in a class where they had an Indigenous faculty member or instructor, or in later applications for Indigenous-specific scholarships or at the time of graduation. Many of these students will never formally notify the institution of their Indigenous identity hence, there are discrepancies in reporting institutional statistics on how many Indigenous students may be enrolled and graduation rates.

Admissions policies also occur at the program level, where some academic areas intentionally designate "seats" or proportional representation policies for Aboriginal students. The goal is to increase Aboriginal representation in particular fields of study, notably medicine, nursing, law, dentistry, and other professional programs such as engineering or business. There are also similar policies related to on-campus accommodations and financial supports (e.g., scholarships, grants).

Within Aboriginal admissions or other policies in some institutions, a tension does exist with selfidentification and institutional processes that require "proof" of Aboriginal ancestry. For students who are registered Band members and/or have status through the Indian Act, this documentation is relatively easy to provide. However, for other Indigenous students, getting this required documentation is more problematic due to the political tensions within their Band or community, separation from their community (e.g., Sixty scoop, foster care, adoption, etc.), or relocation (e.g., growing up in urban settings or communities outside of their ancestral connections or being Indigenous from other countries) (Pidgeon, 2008a, 2008b; Pidgeon, Archibald, \& Hawkey, 2014). University and college then becomes a time for these Aboriginal students to explore, understand, and empower themselves with a better sense of what it means to be Aboriginal. This journey is not an easy one; it is one that must be supported within the Indigenization of the institution and is part of the broader decolonizing project of Canada's education system.

\subsection{Relevance to Curricular \& Co-Curricular}

\subsubsection{Teaching \& Learning}

The academic programs of Native Teacher Education Programs and Native Studies were the first academic points of entry for many Aboriginal students in the late 1960s and to the 1970s (Battiste \& Barman, 1995; Stonechild, 2006). Since the 1990s there has been a diversification of academic majors, minors, and program focuses specifically related to Indigenous perspectives. There have also been targeted recruitment initiatives within the Science, Technology, Engineering, and Mathematics (STEM) fields and medicine to recruit and retain Indigenous engineers, scientists, medical doctors, and nurses (Human Capital Strategies, 2005). Within Teaching and Learning Centers there have been efforts to hire Indigenous curriculum experts to help support faculty to support Indigenous learners in their classrooms through culturally relevant curriculum and pedagogical practices. Libraries are also beginning to embrace Indigenous knowledge system(s) within the library sciences and consequently, hire Indigenous librarians to work specifically with Indigenous content. Within the reconciliation section, the Truth and Reconciliation Commission of Canada (TRC) (2015a) call to action for education for reconciliation calls for curriculum, intercultural competencies, and teacher training-all of these recommendations apply to teaching and learning at university and colleges and certainly align with the Indigenization movement.

Such policy and practices do influence the classroom experiences of students. For example, the Association of Canadian Deans of Education (2011) follow up report demonstrated how the 19 Faculties of Education imple- 
mented the Accord on Indigenous Education from a onetime course to an integrated approach throughout the curriculum. Some institutions have not only created a required course but also have furthered their support in the work of Aboriginal language revitalization and extended (or renewed) their relationships with local First Nations (e.g., St. Francis Xavier University).

In addition to a required course, the Faculty of Education at York University have also moved towards an Infusion model were "it is centered on developing respectful relationship with First Nations, Métis, and Inuit partners and creating space in the program for thoughtful construction of new pedagogy and understandings" (Vetter \& Blimkie, 2011 cited in ACDE, 2011, p. 7) that respect Indigenous ways of knowing and being. Some examples of the work being done across the country include the University of British Columbia where in 2013 the Dean of Education and Associate Dean of Indigenous Education supported the establishment of a professorship in Indigenous Education in Teacher Education, which was directly related to implementation of the Accord. At Simon Fraser University, this mandate has taken a more integrated approach through the Professional Development Program supported through new tenure track hire in Indigenous education and the creation of the Office of Indigenous Education, with an advisory committee to implement the Accord across the Faculty. In 2014, the University of Toronto's Ontario Institute for Studies in Education (OISE) received a gift of five million dollars to strengthen Indigenous education research in Canada. OISE created the endowed chair of William A. Macdonald, Q.C Distinguished Fellow in Indigenous Education ("Indigenous education initative at OISE: Advancing leadership in Indigenous knowledge and education," 2015) and Chief Shawn A-in-chut Atleo was the first appointed to this distinguished chair.

While the Accord was developed for Faculties of Education it does provide a replicable process and relevant programmatic changes for other academic disciplines to follow. The first would be to have Indigenous faculty within the discipline take a leadership role in developing the accord with the support of the Deans of the faculties across the country. This work would center Indigenous knowledge, pedagogies, and practices within the discipline and provide models of how the discipline could take up the work (e.g., required courses to infused across the curriculum). The Deans would be responsible for supporting the implementation of the accord within their respective faculties, as the Deans of Education have done so with the Accord they unanimously signed.

Given the 2015 TRC Calls to Action and recommendations, the Accord leads to the broader question: What about a required course for all undergraduate students? This is the exact call made by the Aboriginal Student Council and the University of Winnipeg Stu- dent Union in February 2015, which would require all undergraduates complete an Indigenous studies course as part of their degree program as a graduation requirement (CBC News, 2015). The Senate of the University of Winnipeg approved in principle the Indigenous course requirement on March 26, 2015 and it will be implemented for Fall 2016 (Communications, 2015). The University of Lakehead is also working towards requiring all incoming undergraduate students to take an Indigenous content course as part of their degree requirements for graduation. The motivation for both institutions is based on social justice, acknowledging the systemic and societal racism and the general lack of awareness and understanding non-Aboriginal Canadians have about Aboriginal peoples history and contemporary issues across the country (Halsall, 2015).

\subsubsection{Student Services}

Student services is considered to oversee the cocurricular aspects of the student experience which include, but are not limited to, housing, counseling, wellness, student leadership, student engagement, financial services, learning commons, and other such support services. Aboriginal student services in Canada were first established in the 1970s in response to a recognized need for culturally relevant support services for Indigenous learners (Pidgeon, 2005; Pidgeon \& Hardy Cox, 2005). The 1990s saw a period of growth due to provincial target funds to further support Aboriginal students in their transition to university with culturally-relevant support services; in 2001 approximately $45 \%$ of public universities had some form of Aboriginal student support (Pidgeon \& Hardy Cox, 2005), and in 2014-2015 my recent review of this original research found more than $90 \%$ of Canadian colleges and universities now have some form of Aboriginal student services.

Across the research projects I have been engaged in, administrators, student service providers, and Aboriginal students expressed some tensions about providing culturally-relevant services to a small percentage of the student population, despite recognizing the inherent value of such services (Pidgeon, 2008a, 2014). Institutionally, this tension arises from government cutbacks to funding post-secondary education generally and establishing Aboriginal-initiatives based on shortterm, often external funding. For student service providers, not only were fiscal limitations expressed, but the acknowledgement that providing Aboriginal student services without institutional commitment to human resources and campus space continues to be difficult. Aboriginal student services provide a home-awayfrom-home for students and both practitioners and Aboriginal students shared experiences of how limited operating budgets impacted services (e.g., limited access to tutoring, computer resources, etc.). Some stu- 
dents shared their observation that while there was a lot of institutional promotion of support of Indigenization, such programs, policies, and services become irrelevant if Aboriginal students themselves were not seeing institutional changes that directly impacted their curricular and co-curricular experiences (Pidgeon, 2008a, 2014).

\subsubsection{Research}

Academic research within Canada is funded primarily through the Tri-Council, which is comprised of three national research councils: Canadian Institute of Health Research (CIHR), Social Sciences and Humanities Research Council (SSHRC), and National Science and Engineering Research Council. Pertinent to this discussion is the Tri-Council's collaborative work with Aboriginal scholars on developing a specific chapter within the TriCouncil Ethical Guidelines that address ethical issues when working with Aboriginal communities. Even in following Chapter 9 of the Tri-Council, researchers must also be aware they need to consult with relevant organizational bodies (e.g., Health or Educational authorities) and of course, Aboriginal communities ethical protocols (Mi'kmaq Ethics Committee and College Institute, 1997; Piquemal, 2001).

Indigenous research methodologies and processes cannot be excluded from this discussion for several reasons. Indigenous scholars are incorporating culturally relevant and responsible research practices in their scholarship. As a result they are bridging relationships with Aboriginal communities that are bound by cultural expectations of ethics as well as academic ethical standards. In the inclusion of Indigenous research methods in the academy, there is a need to change tenure and promotion policies and procedures to not only understand the work of Indigenous researchers. There has to be institutional recognition through policies, like those of tenure and promotion, that acknowledge Indigenous scholars using Indigenous research methodologies will have different research trajectories and dissemination processes within this body of work will look different from traditional research profiles of non-Indigenous scholars (Kovach, 2009; Smith, 2012).

The Canadian Association of University Teachers (CAUT) has been holding bi-annual forums for Aboriginal academic staff to better understand their unique issues of being within the academy and to better support their work. These forums are:

“organized with the guidance of CAUT's Working Group on Aboriginal Post-Secondary Education, this the Forum will be an important opportunity for Aboriginal academic staff from across Canada to get together to share information, discuss issues of common interest, and provide advice to CAUT and our member associations." (Canadian Association of University Teachers (CAUT), 2015, para. 5)

Specific workshops are held regarding tenure and promotion with the aim to change the system structures to be more inclusive for Indigenous academics and those working with Aboriginal communities.

\subsection{Respect in Practice}

Through my research (Pidgeon, 2011, 2014; Pidgeon et al., 2014), I have learned of pockets of presence in our institutions where Indigenization thrives and this work also highlights some ongoing tensions with Indigenization of the academy: How does Indigenization live in practice? How are Indigenous knowledge(s) being respected in our institutions? In thinking about meaningful social inclusion and Indigenization, I have chosen to focus on three tensions that are currently hindering advancing Indigenization in the academy: token checklists vs. meaningful practice, Indigenization vs. Internationalization, and identity contestations.

\subsubsection{Checklist vs. Meaningful Practices}

The institutional checklist approach to Indigenization can be an easy one to write and to say, "Done, done, and done". However, in using the Indigenous Wholistic Framework to create this list, there are deeper questions to ask for. For example, does the institutions Indigenization strategy positively change the lived experiences of Indigenous students, staff, and faculty? Are Aboriginal peoples seeing themselves reflected in the curriculum, the classroom, the hallways, in their academic programs of choice, in the staff room, or at Senate?

In a period of austerity measures for post-secondary education, one avenue for financial support still available is through targeted funding programs (e.g., government, endowments etc.) for Indigenous programs and services (albeit short term and often externally sourced). However, such special initiative funding becomes pointless if the institutions do not commit institutional resources (both human and financial) to the long term sustainability of such initiatives (Pidgeon, 2014). This is not an argument against special initiative funding as such funding can be key catalysts to support institutional change however Indigenization cannot stop here nor be dependent solely on such short-term funding.

In the review of the development of Aboriginal specific student affairs and services, early establishment of such services was a direct result of specific provincial funding programs aimed at increasing support for Aboriginal students (Pidgeon, 2005; Pidgeon \& Hardy Cox, 2005). During the early development of these centres they were often located on the outskirts of campus or located in buildings that required major repair. For other institutions they created Aboriginal-specific 
buildings or gathering spaces in existing buildings were externally funded through endowments and fund raising (Pidgeon, 2014). These buildings, such as the Longhouse at UBC or the Aboriginal Student Centre at the University of Winnipeg represent culturally appropriate Indigenous architecture. Other models, such as the services provided at Western University through Indigenous Services, the First Nations House at University of Toronto, or the Indigenous student centre and Aboriginal gathering spaces at Simon Fraser University all of which reclaimed institutional space and included culturally-appropriate artwork, physical spaces (e.g., circle lounges), and other modifications that represented Indigenity.

Indigenous initiatives for systemic change and sustainability require clear funding commitments that are not dependent on the securing of the next grant. Governments change as do political will-so for Indigenization of the academy to have a lasting legacy for the next seven generations it must be sustainable and integrated, not an add on approach that is limited by funding. This funding flux is also related to another tension evident in higher education between Indigenization and internationalization.

\subsubsection{Indigenization \& Internationalization}

The increasing influence of globalization and neoliberalism on the discourses of access to higher education requires institutions to be mindful of the tensions in the internationalization movements and the Indigenization movements (Garson \& Dumouchel, 2013). In today's reality there is a competition of resources that challenges how institutional resources (both human and financial) are directed to each initiative. In some instances, these two movements are seen as opposing and competing for institutional resources. However, assumptions can not be made that creates a binary of Indigenous or International. When in fact, Aboriginal peoples can also be from international context and attend Canadian post-secondary institutions. What is needed are equitable approaches to decolonization and intercultural development, as part of Indigenization, to not only meet Indigenous peoples were they are (e.g., physically increasing access to digital and face-to-face learning environments) but also ensuring high quality programs and services. Indigenization, as the Truth and Reconciliation Report calls for, is about increasing understanding of non-Aboriginal peoples to become decolonized in order to truly value the contributions of the past, present, and future of Indigenous peoples.

\subsubsection{Identity Contestations}

The politicization of Indigenous identity plays out in the academy, from those claiming identity that is not theirs to claim for personal financial or professional gain (Pewewardy, 2004), to those students and scholars re- claiming their Aboriginal identity as a decolonization process (Huffman, 2001; Pidgeon, 2014). As Daniel Justice Heath reminds us:

"If nationhood and liberation are our goals, we must truly acknowledge the diversity of Native experiences by avoiding both the traps of 'mixed-blood angst' and of 'full-blood purity' - if we focus on blood quantum as an indicator of Indian 'authenticity,' we emphasize a colonist paradigm that was imposed on $\mathrm{Na}$ tive peoples for the sole purpose of destroying our Nations, traditions, and landbases. Such a focus ignores the wide variety of response to different communities to colonialism and it sets up arbitrary idea of what makes a 'real' Indian....Similarly these trips ignore the fact that we aren't just another immigrant ethnics group-we're independent tribal $\mathrm{Na}$ tions, with governments and distinctive identities of our own that emerge from our spiritual and cultural relationships to this land." (p. 104)

Building on the earlier discussion of whether students choose to self-identify as Aboriginal, Indigenous students who enter university and/or college with their own aspirations of success. Indigenous student success is not only about graduation but is also about being empowered as Indigenous peoples with their cultural integrity intact (Pidgeon, 2008b). It is critical Indigenous and non-Indigenous peoples remain cognizant of the colonial project of "divide and conquer", where by what counts as "Indigenous" becomes another colonial tool to further distract Indigenous peoples from their own rights of self-determination and defining nationhood for themselves. For this to occur, for Indigenization to thrive within the academy-the next section explores the question "What do Indigenized public colleges and universities look like?"

\section{What Does a "Successfully" Indigenized Public College or University Look Like?}

System transformations require not only recognition of institutional responsibility to Indigenous peoples, but also articulated accountability to these responsibilities (Pidgeon, 2014). Indigenization of the academy has truly transformed higher education when Indigenous students leave the institution more empowered in who they are as Indigenous peoples and when non-Indigenous peoples have a better understanding of the complexities, richness, and diversity of Indigenous peoples, histories, cultures, and lived experiences. Indigenizing the academy can be enacted Indigenous representation from the Board of Governors, Senate, and senior administration to the faculty, staff, and students. It is about having relevant curricular and co-curricular program, policies, and services in place that truly honor who Indigenous students are in their journey (Pidgeon, 2008b). 
There is still the question of when will we know that an institution has successfully Indigenized (from Indigenous understandings of what that means). For example, an Indigenized public post-secondary institution may have institution-wide policies, such as Aboriginal strategic plans; proportional representation of administrators, faculty, and staff who are Indigenous; culturally relevant programs, policies, services, and practices across each faculty and department, and an ongoing commitment to Indigenization. Several questions might be posed to institutions undertaking Indigenization: what changes can we see in the lived experiences of Indigenous student? Are there changes in recruitment and retention of Indigenous students, faculty, and staff? How do Aboriginal communities experience these institutions and the students who return home from these places? Even more broadly, to ask Indigenous peoples what their expectations are of such institutions and what societal and systemic changes will need to be witnessed and more importantly experienced by Indigenous peoples. These questions will be answered in the near future as we will be able to examine institutional practices and outcomes related to their Indigenization efforts.

\section{Conclusions}

The overall theme of this journal relates to social inclusion of Indigenous peoples and this article positions Indigenization in higher education as one movement that can reconcile disparities that currently exist in our educational systems and societies for Indigenous peoples. System wide and institutional transformation will take time and while Indigenous peoples have been experiencing colonization for over 500 years, we do not have another 500 years to wait for change. The change is happening as Indigenous peoples live in these academic spaces and Indigenization must continue to regenerate and live for generations to come. The true Indigenization of higher education and for meaningful social inclusion of Indigenous peoples, Indigenity must remain at the core of the transformation, centred and grounded in the local territories and nations upon which colleges and universities reside. Non-Aboriginal peoples must take responsibility and be part of their own decolonizing process and move towards reconciliation. In a Indigenized institution, Indigenous peoples remain empowered in their self-determination and cultural integrity. Ultimately, higher education through Indigenization becomes a place for Aboriginal peoples to journey to attain their envisioned futures.

\section{Acknowledgments}

I raise my hands in thanks to those who have participated and partnered in research with me over years. It is the voices of Aboriginal students, Elders, administra- tors, faculty, and staff that are central to this work and the continued efforts each of them make in moving forward Indigenization in the academy. I would also like to acknowledge and pay respect to the nonIndigenous administrators, faculty, and staff who have worked alongside with Indigenous peoples to make transformational change within the institution for Indigenous peoples and their communities.

\section{Conflict of Interests}

The author declares no conflict of interests.

\section{References}

Academia Group. (2015, July 13). New uSask President committes to indigenization. Retrieved from http:// academica.ca/top-ten/new-usask-presidentcommits-indigenization

Alfred, T. (2004). Warrior scholarship. In D. A. Mihesuah \& A. C. Wilson (Eds.), Indigenizing the academy: Transforming scholarship and empowering communities (pp. 88-99). Lincoln, Nebraska: University of Nebraska Press.

Arndt, G. (2013). Indigenous dance and dancing indian: Contested representation in the global era by Matthew Krystal (review). The Americas, 70(1), 109111. doi:10.1353/tam.2013.0082

Association of Canadian Deans of Education (ACDE). (2009). Accord for Indigenous Education. Retrieved from http://www.csse-scee.ca/docs/acde/acde_ accord_indigenousresearch_en.pdf

Association of Canadian Deans of Education (ACDE). (2011). Accord for indigenous education: Progress report 2011. Retrieved from http://www.cssescee.ca/docs/acde/acde_indigenousaccord_progres sreport.pdf

Association of Universities and Colleges of Canada (AUCC). (2010). Answering the call: The 2010 inventory of Canadian university programs and services for Aboriginal students. Retrieved from Ottawa: http://www.univcan.ca/wp-content/uploads/2012/ 01/aboriginal-directory-repertoire-autochtone2010.pdf

Battiste, M. (1998). Enabling the autumn seed: Toward a decolonized approach to Aboriginal knowledge, language, and education. Canadian Journal of $\mathrm{Na}$ tive Education, 22(1), 16-27.

Battiste, M. (2013). Decolonizing education: Nourishing the learning spirit. Saskatoon, SK: Purich.

Battiste, M., \& Barman, J. (Eds.). (1995). First Nations education in Canada: Circle unfolds. British Columbia: University of British Columbia.

Battiste, M., Bell, L., \& Findlay, L. M. (2002). Decolonizing education in Canadian universities: An interdisciplinary, international, Indigenous research project. Canadian Journal of Native Education, 26(2), 82-95. 
Billy Minnibarriet, V. (Ed.). (2012). Aboriginal postsecondary education in British Columbia: Nicola valley institute of technology-"An eagle's gathering place". University of British Columbia, Vancouver. Retrieved from http://www.collectionscanada.gc.ca/ obj/thesescanada/vol2/BVAU/TC-BVAU-42089.pdf

Brant Castellano, M. (2014). Indigenizing education. Retrieved from http://www.cea-ace.ca/blog/marlenebrant-castellano/2014/06/2/indigenizing-education

Brant Castellano, M., Davis, L., \& Lahache, L. (Eds.). (2000). Aboriginal education: Fulfilling the promise. Vancouver: UBC Press.

Canadian Association of University Teachers (CAUT). (2015). Forum for Aboriginal academic staff. Retrieved from http://events.caut.ca/aboriginal-2015/

CBC News. (2015). UWinnipeg students' union calls for mandatory indigenous course. Retrieved from http://www.cbc.ca/news/canada/manitoba/uwinnip eg-students-union-calls-for-mandatory-indigenouscourse-1.2958811

College and Institutes Canada. (2014a). Indigenous education protocol. Retrieved from http://www.colleges institutes.ca/policyfocus/indigenous-learners/approa ches-and-exemplary-practices-to-guide-implementat ion

College and Institutes Canada. (2014b). Indigenous learners. Retrieved from http://www.colleges institutes.ca/policyfocus/indigenous-learners

Communications. (2015, March 26). Senate approves principle of Indigenous course requirement. Retrieved from http://news-centre.uwinnipeg.ca/all-posts/se nate-approves-principle-of-indigenous-courserequirement

Cupples, J., \& Glynn, K. (2014). Indigenizing and decolonizing higher education on Nicaragua's Atlantic Coast. Singapore Journal of Tropical Geography, 35(1), 56-71. doi:10.1111/sjtg.12051

Dorion, J., \& Yang, K. R. (2000). Métis post-secondary education: a case study of the Gabriel Dumont Institute. In M. Brant Castellano, L. Davis, \& L. Lahache (Eds.), Aboriginal education: Fulfilling the promise (pp. 176-189). Vancouver: UBC Press.

Francis-Begay, K. (2013). The role of special advisor to the president on Native American Affairs. In H. Shotton, S. C. Lowe, \& S. J. Waterman (Eds.), Beyond the asterisk: Understanding native students in higher education (pp. 81-94). Sterling, VA: Stylus.

Garson, K., \& Dumouchel, L. (2013). G2: Internationalization and Indigenization: Finding the synergies. Paper presented at the CBIE, Vancouver, BC. Retrieved from http://www.cbie-bcei.ca/wp-content/uploads/ 2013/08/G2-Internationalization-andIndigenization.pdf

Halsall, J. (2015, June 23). Some univerisities look to adopt indigenous course requirements. University Affairs/Affaires universitaires. Retrieved from http://www.universityaffairs.ca/news/news- article/some-universities-look-to-adopt-indigenouscourse-requirements

Hare, J., \& Pidgeon, M. (2011). The way of the warrior: Indigenous youth navigating the challenges of schooling. Canadian Journal of Education, 34(2), 93111. Retrieved from http://search.proquest.com. proxy.lib.sfu.ca/docview/881643999?accountid=138 00

Huffman, T. (2001). Resistance theory and the transculturation hypothesis as explanations of college attrition and persistence among culturally traditional American Indian students. Journal of American Indian Education, 40(3), 1-23.

Human Capital Strategies. (2005). Review of Aboriginal post-secondary education programs, services, and strategies/best practices and Aboriginal special projects funding (ASPF) program. Retrieved from http://www.humancapitalstrategies.ca/download/fi nal_report_june_30-05.pdf

Indigenous education initative at OISE: Advancing leadership in Indigenous knowledge and education. (2015). Retrieved from https://www.oise.utoronto. ca/oise/UserFiles/File/IndigenousInitiaties2015.pdf

Jacobs, M. R. (2014). Race, place, and biography at play: Contextualizing American Indian viewpoints on Indian mascots. Journal of Sport \& Social Issues, 38(4), 322-345. doi:10.1177/0193723514530568

Jones, G. A. (2014). An introduction to higher education in Canada. In K. M. Joshi \& S. Paivandi (Eds.), Higher education across nations (Vol. 1, pp. 1-38). Delhi: B. R. Publishing.

Justice, D. H. (2004). Seeing (and reading) red. In D. A. Mihesuah \& A. C. Wilson (Eds.), Indigenizing the academy: Transforming scholarship and empowering communities (pp. 100-123). Lincolin: University of Nebraska Press.

King, C. R., \& Springwood, C. F. (Eds.). (2001). Team Spirits: The Native American mascots controversy. Retrieved from http://www.ebrary.com

Kirkness, V. J., \& Barnhardt, R. (1991). First Nations and higher education: The four R's-Respect, relevance, reciprocity, responsibility. Journal of American Indian Education, 30(3), 1-15. Retrieved from http://jaie. asu.edu/v30/V30S3fir.htm

Kovach, M. (2009). Indigenous methodologies: Characteristics, conversations, and contexts. Buffalo: University of Toronto Press.

Kuokkanen, R. (2007). Reshaping the university: Responsibility, Indigenous epistemes and the logic of the gift. Vancouver: UBC Press.

Lee, S., \& Castagno, A. (2007). Native mascots and ethnic fraud in higher education: Using tribal critical race theory and the interest convergence principle as an analytic tool. Equity \& Excellence in Education, 40(1), 3-13. doi:10.1080/10665680601057288

Malatest, R. A., \& Associates Ltd. (2004). Aboriginal peoples and post-secondary education: What educators 
have learned. Retrieved from http://www.millen niumscholarships.ca

Marker, M. (2004). The Four Rs revisited: Some reflections on First Nations and higher education. In L. Andres \& F. Finlay (Eds.), Student affairs: Experiences in and through Canadian post-secondary education (pp. 171-188). Vancouver, BC: UBC Press.

Mi'kmaq Ethics Committee and College Institute. (1997). Mi'kmaq research ethics and protocols. Retrieved from http://mrc.uccb.ns.ca/prinpro.html

Mihesuah, D. A., \& Wilson, A. C. (Eds.). (2004). Indigenizing the academy: Transforming scholarship and empowering communities. Lincoln, NE: University of Nebraska Press.

National Indian Brotherhood. (1972). Indian control of Indian education. Ottawa: National Indian Brotherhood.

Paquette, J., \& Fallon, G. (2014). In quest of Inidgenity, quality, and credibility in Aboriginal post-secondary education in Canada: Problematic, contexts, and potential ways forward. Canadian Journal of Educational Administration and Policy, 165, 1. Retrieved from http://www.umanitoba.ca/publications/cjeap/pdf_fil es/paquette_fallon.pdf

Pewewardy, C. D. (2004). So you think you hired an "Indian" faculty member? In D. A. Mihesuah \& A. C. Wilson (Eds.), Indigenizing the academy: Transforming scholarship and empowering communities (pp. 200217). Lincoln, NE: University of Nebraska Press.

Pewewardy, C. D. (2013). Fancy war dancin on academe's glass ceiling: Supporting and increasing Indigenous faculty role models in higher education In H. Shotton, S. C. Lowe, \& S. J. Waterman (Eds.), Beyond the asterisk: Understanding native students in higher education (pp. 139-150). Sterling, VA: Stylus.

Pidgeon, M. (2005). Weaving the story of Aboriginal student services in Canadian unviersities. Communique, 5(3), 27-29.

Pidgeon, M. (2008a). It takes more than good intentions: Institutional accountability and responsiblity to Indigenous higher education (Doctoral Thesis). University of British Columbia, Vancouver, Canada.

Pidgeon, M. (2008b). Pushing against the margins: Indigenous theorizing of "success" and retention in higher education. Journal of College Student Retention: Research, Theory \& Practice, 10(3), 339-360. doi:10. 2190/CS.10.3.e

Pidgeon, M. (2011). Imagining Douglas College as a successful place for Aboriginal students. Unpublished Research Report, Vancouver, BC.

Pidgeon, M. (2014). Moving beyond good intentions: Indigenizing higher education in British Columbia universities through Institutional responsiblity and accountability. Journal of American Indian Education, 53(2), 7-28.

Pidgeon, M., Archibald, J.-a., \& Hawkey, C. (2014). Relationships Matter: Supporting Aboriginal graduate students in British Columbia, Canada. Canadian Journal of Higher Education, 44(1), 1-21. Retrieved from http://proxy.lib.sfu.ca/login?url=http://search.ebsco host.com/login.aspx?direct=true $\& \mathrm{db}=$ eric $\& A N=E J 10$ 28743\&site=ehost-live

Pidgeon, M., \& Hardy Cox, D. (2005). Perspectives of Aboriginal student services professionals: Aboriginal student services in Canadian universities. Journal of Australian \& New Zealand Student Services, 25, 3-30.

Pidgeon, M., Muñoz, M., Kirkness, V. J., \& Archibald, J.-a. (2013). Indigenous control of Indian education: Reflections and envisioning the next 40 years. Canadian Journal of Native Education, 36(1), 5-35.

Piquemal, N. (2001). Free and informed consent in research involving Native American communities. American Indian Culture and Research Journal, 25(1), 65-79.

Royal Commission on Aboriginal Peoples. (1996). Gathering of strength, Volume 3. Report of the Royal Commission on Aboriginal Peoples (RCAP). Ottawa: Minister of Supply and Services.

Shotton, H., Lowe, S. C., \& Waterman, S. J. (Eds.). (2013). Beyond the asterisk: Understanding Native students in higher education. Sterling, VA: Stylus.

Smith, L. T. (2012). Decolonizing methodologies: Research and indigenous peoples. New York: Zed Books.

Statistics Canada. (2008). Aboriginal statistics at a glance. Retrieved from http://www.statcan.gc.ca/ pub/89-645-x/89-645-x2010001-eng.htm

Statistics Canada. (2013). 2011 National Household Survey. Retrieved from http://www12.statcan/gc/ca/ nhs-enm/2011/as-sa/99-011-x/2011001/tbl/tbl02eng.cfm

Stonechild, B. (2006). The new buffalo: The struggle for Aboriginal post-secondary education in Canada. Winnipeg, MB: University of Manitoba Press.

The Aboriginal Institutes' Consortium. (2005). Aboriginal institutions of higher education: A struggle for the education of Aboriginal students, control of Indigenous knowledge, and recognition of Aboriginal institutions. Retrieved from http://caid.ca/AboHigEdu 2005.pdf

Truth and Reconciliation Commission of Canada (TRC). (2015a). Honoring the truth, reconciling for the future: Summary of the final report of the Truth and Reconciliation Commission of Canada. Retrieved from http://www.trc.ca/websites/trcinstitution/File/ 2015/Honouring_the_Truth_Reconciling_for_the_Fu ture_July_23_2015.pdf

Truth and Reconciliation Commission of Canada (TRC). (2015b). The Truth and Reconciliation Commission of Canada: Calls to action. Retrieved from http:// www.trc.ca/websites/trcinstitution/File/2015/Findin gs/Calls_to_Action_English2.pdf

Usher, A. (2009). The Post-Secondary Student Support Program: An examination of alternative delivery 
mechanisms. Retrieved from http://www.educa tionalpolicy.org/publications/pubpdf/INAC.pdf

White, J. P., Maxim, P. S., \& Spence, N. D. (2004). An examination of educational success. In J. P. White, P. S. Maxim, \& D. Beavon (Eds.), Aboriginal policy research: setting the agenda for change (Vol. 1, pp. 129-148). Toronto: Thompson.
Wotherspoon, T., \& Schissel, B. (1998). Marginalization, decolonization and voice: Prospects for Aboriginal education in Canada. Retrieved from http://proxy. lib.sfu.ca/login?url=http://search.ebscohost.com/log in.aspx?direct=true \&db=eric\&AN=ED467991\&site=e host-live

\section{About the Author}

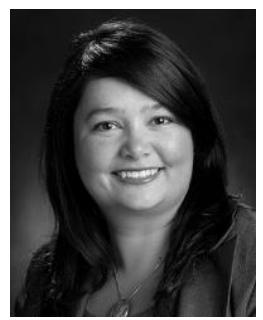

Dr. Michelle Pidgeon

Dr. Michelle Pidgeon's ancestry and family are from Newfoundland and Labrador and she is currently living and working in the traditional and unceded territories of the Coast Salish peoples. She is an Associate professor in the Faculty of Education at Simon Fraser University, British Columbia. She is also the Editor of the Canadian Journal of Higher Education. Dr. Pidgeon is passionate about higher education, student services, and Indigenity. A central tenant of her work is that success is defined and articulated through an Indigenous wholistic framework and research process. 